\title{
PERLINDUNGAN HUKUM TERHADAP HAK PEKERJA YANG DIPUTUS HUBUNGAN KERJANYA KARENA PEKERJA MENOLAK MUTASI PADA PT SANGGRAHA DHIKA (STUDI KASUS PUTUSAN NOMOR 210/PDT.SUS-PHI/2016/PN.JKT.PST)
}

\author{
Sella Haryanto \\ (Mahasiswi Program S1 Fakultas Hukum Universitas Tarumanagara) \\ (Email: sellahary@gmail.com)
}

\section{Andari Yurikosari}

(Corresponding Author)

(Dosen Hukum Pidana Fakultas Hukum Universitas Trisakti, Meraih Sarjana Hukum dari Fakultas Hukum Universitas Indonesia, Magister Hukum dari Fakultas Hukum Indonesia, Doktor Hukum dari Fakultas Hukum Universitas Indonesia)

(Email: andari.yurikosari@gmail.com)

\begin{abstract}
Employees hold an importat role in a company. The importance of employees can be found in Article 32 of Indonesian's Labor Law 2003. Article 32 stated that an employee's mutation must be protected by the law and be subjected to their capabilities and abilities. Therefore the rights of employees are protected by the law. In reality it is difficult to implement the regulation that has been made. Employees mutation without concerning on their capabilities and abilties often happen. This often leds to the termination of contract between the parties involved which results in unfulfilled employee's rights by the company. Related to the verdict of Central Jakarta Industrial Relations Court number 210/Pdt.sus-Phi/2016/Pn.Jkt.Pst the employee as the plaintiff was mutated to a ifferent field of work which is not his ability but instead the court's verdict inflicted a financial loss to the plaintiff as the plaintiff didn't obtain his rights in accordance of Article 156 of Indonesian's Labor Law 2003.
\end{abstract}

Keywords: Work termination, Employee mutation, Legal protection 


\section{PENDAHULUAN}

\section{A. Latar Belakang}

Kehidupan setiap manusia mempunyai kebutuhan pokok yaitu sandang, pangan dan papan, tentu saja dalam memenuhi kebutuhannya manusia harus berusaha. Usaha yang dilakukan adalah dengan bekerja, bahkan manusia cenderung menjadi pekerja keras agar memperoleh hidup layak. Seorang pekerja keras tidak menjamin akan memperoleh penghidupan yang layak, contohnya buruh pabrik, tukang sampah, dan profesi-profesi lainnya yang dinilai hanya menggunakan tenaga dibayar rendah untuk pekerjaan mereka karena di dalam dunia pekerjaan yang lebih dipentingkan adalah tingkat pendidikan dan kemampuan yang tinggi.

Hal ini menjadikan pekerjaan sebagai hal yang penting dan merupakan sebuah hak bagi manusia untuk memilki pekerjaan dalam rangka memenuhi kebutuhan hidupnya. Pentingnya pekerjaan dapat dilihat dari diundangkannya berbagai peraturan seputar pekerjaan. Dalam Pasal 27 Ayat (2) Undang-Undang Dasar Negara Republik Indonesia Tahun 1945 menyatakan bahwa tiap-tiap warga negara berhak atas pekerjaan dan penghidupan yang layak bagi kemanusiaan. Pengaturan ini dipertegas oleh Undang-Undang Nomor 39 Tahun 1999 tentang Hak Asasi Manusia dalam salah satu pasalnya yang menyatakan setiap orang baik pria maupun wanita yang melakukan pekerjaan yang sama, sebanding, setara atau serupa, berhak atas upah serta syarat-syarat perjanjian kerja yang sama.

Bekerja dapat dilakukan dengan membuka usaha sendiri ataupun bekerja dengan orang lain. Pekerjaan yang diusahakan sendiri maksudnya adalah bekerja atas usaha modal dan tanggunjawab sendiri. Sedangkan bekerja pada orang lain maksudnya adalah bekerja dengan bergantung pada orang lain yang memberi perintah dan mengutusnya, karena ia harus tunduk dan patuh pada orang lain yang memberikan pekerjaan tersebut. ${ }^{1}$ Bekerja pada orang lain dapat diartikan orang

${ }^{1}$ Zainal Asikin, Dasar-Dasar Hukum Perburuhan, Cetakan ke-1,(Jakarta: Raja Grafindo Persada, 2004), hal.1. 
tersebut bekerja di luar hubungan kerja (yang meliputi swapekerja atau wiraswasta) dan mereka yang bekerja di dalam hubungan kerja). ${ }^{2}$

Berbicara masalah bekerja tentu kita tidak lupa akan istilah buruh, buruh adalah orang yang bekerja pada suatu perusahaan dan terikat dengan majikan perusahaan dalam suatu pekerjaan dan mendapat upah sesuai dengan ketentuan dan perjanjian. Sedangkan tenaga kerja adalah seseorang yang dapat melaksanakan pekerjaan yang kadang-kadang terikat maupun bebas. Perlu diketahui juga Hukum Perburuhan (Ketenagakerjaan) adalah himpunan peraturanperaturan, baik tertulis maupun tidak tertulis yang berkenaan dengan kejadian dimana seseorang bekerja pada orang lain dengan menerima upah. ${ }^{3}$

Kedudukan buruh dengan pengusaha sebagai manusia adalah sama, tetapi karena ada keterikatan dalam perjanjian kerja maka mau tidak mau buruh akan tunduk pada peraturan dan perintah kerja dari pengusaha. Demikian juga pengusaha dalam memerintah buruh tidak boleh semena-mena, tetapi harus seirama dengan ketentuan perundang-undangan yang berlaku bahkan harus sesuai dengan keadaan sarana-sarana pendukungnya. ${ }^{4}$ Tidak dapat disangkal bahwa pengusaha dapat juga menempatkan buruh pada posisi-posisi yang telah diaturnya, namun hal ini harus disertai dengan kelayakan, sehingga buruh dapat sebagai partner usaha akan dapat menunjukkan loyalitasnya. Walaupun antara buruh dan pengusaha telah diatur berbagai hak dan kewajiban, itu kurang dapat dipenuhi sepenuhnya sehingga dapat menimbulkan perselisihan.

Meskipun undang-undang tersebut tidak melarang sesuatu pihak untuk melakukan tindakan terhadap pihak lainnya dalam perselisihan perburuhan, tetapi mengandung jiwa untuk mencegah pihak yang satu mengadakan tindakan untuk pihak lainnya. Jenis perselisihan yang sering timbul antara pekerja dan pengusaha adalah perselisihan pemutusan hubungan kerja, di mana kondisi seperti ini akan berpengaruh bagi kehidupan si buruh maupun keluarganya. Melihat keadaan

\footnotetext{
${ }^{2}$ Asri Wijayanti, Hukum Ketenagakerjaan Pasca Reformasi, Cetakan ke-4, (Jakarta: Sinar Grafika, 2014), hal.4. 2003), hal.2.

${ }^{3}$ Imam Soepomo, Pengantar Hukum Perburuhan, Cetakan ke-13, (Jakarta: Djambatan,

${ }^{4}$ Y.W. Sunindhia, Masalah Pemutusan Hubungan Kerja dan Pemogokan, Cetakan ke-1, (Jakarta: Bina Aksara, 1988), hal.163.
} 
seperti ini perlu diadakan ketentuan mengenai pemutusan hubungan kerja dengan memperhatikan kepentingan kedua belah pihak, baik pengusaha maupun buruh dengan mengadakan penyelesaian yang layak. Jika suatu perusahaan tidak dapat menghindari pemutusan hubungan kerja, maka pihak pengusaha sebenarnya harus merundingkan maksudnya tersebut dengan pekerjanya sendiri, jika buruh tersebut tidak menjadi anggota organisasi buruh yang ada. ${ }^{5}$

Praktik pemutusan hubungan kerja dapat dilakukan oleh salah satu pihak baik pengusaha maupun pekerja. Luasnya cakupan masalah perselisihan pemutusan hubungan kerja maka tidak heran bahwa perlindungan paling banyak dalam peraturan ketenagakerjaan adalah mengenai pemutusan hubungan kerja. Hal ini wajar karena masalah pemutusan hubungan kerja menyangkut kelangsungan hidup para pekerja selanjutnya. Sebelum terjadinya pemutusan hubungan kerja, pekerja dapat dikenakan skorsing terlebih dahulu. Pihak perusahaan harus memberikan 3 kali surat peringatan kepada pekerja. Jika pemutusan hubungan kerja tidak bisa dihindari pada akhirnya maka wajib dirundingkan oleh pengusaha dan serikat pekerja atau dengan pekerja bila pekerja yang bersangkutan bukan anggota serikat pekerja. Jika perundingan pengusaha dan pekerja tidak menghasilkan persetujuan, pekerja hanya dapat diputus hubungan kerjanya setelah ada penetapan dari Pengadilan Hubungan Industrial. Selain Pengadilan Hubungan Industrial, lembaga penyelisihan perselisihan hubungan industrial bisa melalui mediasi, konsiliasi, maupun arbitrase.

Pada dasarnya, ketentuan mengenai pemutusan hubungan kerja antara pengusaha dengan pekerja sudah diatur dan disepakati bersama baik dalam Perjanjian Kerja Bersama, Peraturan Perusahaan serta Undang-Undang Nomor 13 Tahun 2003 tentang Ketenagakerjaan. Dari sekian banyak alasan untuk memutuskan hubungan kerja antara pengusaha dengan pekerja, pemutusan hubungan kerja haruslah dilakukan sesuai dengan ketentuan yang sudah disepakati. Pemindahan pekerja atau yang dikenal dengan mutasi. Ketentuan mengenai mutasi pada umumnya sudah diatur dalam ketentuan undang-undang serta sudah disepakati oleh para pihak. Pada praktiknya seringkali terjadi masalah

\footnotetext{
${ }^{5}$ Ibid.,hal.165.
} 
dalam mutasi yang dilakukan oleh pengusaha terhadap pekerja. Mutasi sering dijumpai yang dilakukan oleh pengusaha terhadap pekerja menyalahi ketentuan yang ada.

Pengertian mutasi menurut Nitisemito adalah kegiatan dari pimpinan perusahaan untuk memindahkan karyawan dari suatu pekerjaan ke pekerjaan lain yang dianggap setingkat atau sejajar. Undang-Undang Nomor 13 Tahun 2003 tentang Ketenagakerjaan, mengenal istilah mutasi, hal ini dapat ditemukan dalam penjelasan Pasal 143 Undang-Undang Nomor 13 Tahun 2003 tentang Ketenagakerjaan. Pengaturan mengenai mutasi tidak secara eksplisit diatur, namun salah satu pasal dalam Undang-Undang Nomor 13 Tahun 2003 tentang Ketenagakerjaan mengatur perihal penempatan tenaga kerja yang erat kaitannya dengan mutasi.

Pasal 32 Ayat (2) Undang-Undang Nomor 13 Tahun 2003 tentang Ketenagakerjaan menyatakan bahwa penempatan tenaga kerja diarahkan untuk menempatkan tenaga kerja pada jabatan yang tepat sesuai dengan keahlian, ketrampilan, bakat, minat, dan kemampuan dengan memperhatikan harkat, martabat, hak asasi, dan perlindungan hukum.

Penjelasan diatas menggambarkan bahwa dapat dipahami bahwa penempatan tenaga kerja yang dilakukan oleh pengusaha harus sejalan dengan ketentuan Pasal 32 Ayat (2) Undang-Undang Nomor 13 Tahun 2003 tentang Ketenagakerjaan, pengusaha tidak bisa menempatkan tenaga kerja di tempat yang tidak sesuai dengan keterampilan yang ia miliki.

Pelaksanaan ketentuan Pasal 32 Ayat (2) Undang-Undang Nomor 13 Tahun 2003 tentang Ketenagakerjaan masih menemui banyak kendala. Banyak pengusaha yang mengesampingkan ketentuan tersebut. Contohnya pada tahun 2017 di Jambi terjadi kasus pengusaha yang memutasi pekerjanya tanpa memperhatikan ketentuan Pasal 32 Ayat (2) Undang-Undang Nomor 13 Tahun 2003 tentang Ketenagakerjaan. Perusahaan dinilai telah melanggar perjanjian kerja, karena mempekerjakan pekerja yang semula dibagian produksi ke bagian yang lebih rendah yaitu security. Pekerja pun mengajukan gugatan atas perusahaan ke Pengadilan Hubungan Industrial Jambi. Gugatan tersebut 
dikabulkan oleh Pengadilan Hubungan Industrial Jambi dan diperkuat oleh Mahkamah Agung.

Penulisan skripsi ini membahas mengenai perlindungan hukum terhadap pekerja yang diputus hubungan kerjanya, karena menolak mutasi oleh perusahaan yang seharusnya dilakukan sesuai dengan ketentuan dalam Undang-Undang Nomor 13 Tahun 2003 tentang Ketenagakerjaan dan Perjanjian Kerja Bersama antara pengusaha dengan pekerja. Pekerja yang dimaksud bernama Nana Kusnaedi sudah bekerja selama 16 tahun di PT Sanggraha Dhika (REDTOP Hotel and Convention Center) bertempat di Jakarta Pusat. Masalah muncul ketika Nana dimutasi oleh PTSanggraha Dhika yang semula dari Gardening menjadi Food and Beverage di mana Food and Beverage bukan merupakan keahlian dari Nana karena ia sudah bekerja selama 19 tahun sebagai Gardener sehingga merupakan hal yang wajar bila Nana menolak untuk dimutasi karena Food and Beverage, bukanlah keahlian yang ia kuasai. Nana pun kemudian menyampaikan keluhannya atas mutasi tersebut kepada bagian personalia perusahaan. Namun keluhan tersebut tidak ditanggapi dan perusahaan hanya memberi alasan pada Nana bahwa pemutusan hubungan kerja dilakukan berdasarkan kepentingan perusahaan. Pada hari berikutnya Nana mendapati dirinya diputus hubungan kerjanya oleh perusahaan. Hal ini dirasa tidak adil karena Nana dimutasi ke bidang yang tidak sesuai keahliannya sebagaimana yang sudah diatur dalam Undang-Undang Nomor 13 Tahun 2003 tentang Ketenagakerjaan dan Perjanjian Kerja Bersama yang dibuat antara perusahaan dengan serikat buruh. Mediasi pun dilakukan dalam upaya mendamaikan kedua belah pihak namun tidak membuahkan hasil. Sehingga perselisihan ini pun diteruskan hingga ke Pengadilan Hubungan Industrial.

Pengadilan Hubungan Industrial dalam memutus gugatan pekerja menyangkut pemberian kompensasi pemutusan hubungan kerja dan hak-hak lainnya yang seharusnya diterima hanya didapatkan sebagian dari yang seharusnya. Hakim Pengadilan Hubungan Industrial Jakarta Pusat memutus dalam putusan bernomor 210/Pdt.Sus-PHI/2016/PN.JKT.PST bahwa gugatan pekerja dikabulkan sebagian di mana elemen-elemen hak yang harus diterima oleh penggugat yang telah bekerja selama 16 tahun yakni uang pesangon, uang 
penghargaan masa kerja dan uang penggantian hak tidak didapatkan. Penggugat hanya mendapatkan uang pisah sebesar Rp. 6.646 .000 (enam juta enam ratus empat puluh enam ribu rupiah). Hasil putusan ini tentu sangat berselisih jauh dari petitum surat gugatan penggugat. Hal ini tentu sangat mengherankan mengingat masa kerja penggugat di PT Sanggraha Dhika namun uang pemutusan hubungan kerja yang seharusnya diterima tidak didapatkan.

\section{B. PERMASALAHAN}

Berdasarkan latar belakang sebagaimana diuraikan di atas, permasalahan yang dikaji dalam artikel ini adalah:

1. Bagaimana perlindungan hukum terhadap hak pekerja yang diputus hubungan kerjanya karena pekerja menolak mutasi pada PT Sanggraha Dhika (Studi Kasus Putusan Nomor 210/Pdt.Sus-PHI/2016/PN.JKT.PST)?

2. Bagaimana akibat hukum terhadap pekerja yang diputus hubungan kerjanya karena menolak mutasi pada PT Sanggraha Dhika (Studi Kasus Putusan Nomor 210/Pdt.Sus-PHI/2016/PN.JKT.PST)?

\section{PEMBAHASAN}

\section{A. Perlindungan Hukum Terhadap Hak Pekerja Yang DiputusHubungan Kerjanya Karena Pekerja Menolak Mutasi Pada PT Sanggraha Dhika (Studi Kasus Putusan Nomor 210/Pdt.Sus-PHI/2016/PN.JKT.PST)}

Nana Kusnaedi merupakan karyawan REDTOP Hotel \& Convention Center dengan jabatan sebagai Waiter F \& B Service pada F \& B Dept. dengan masa kerja selama 16 tahun lebih. Penggugat menerima upah terakhir pada bulan November 2015 seluruhnya sebesar Rp. 3.323.000, dengan komponen upah yang terdiri dari upah pokok sebesar Rp. 3.103.000 ditambah dengan tunjangan tetap sebesar Rp. 220.000 per bulan. Selain sebagai karyawan, penggugat juga merupakan pengurus Serikat Pekerja Anggota (SPA) dan/atau berafiliasi kepada Federasi Serikat Pekerja Pariwisata dan Sektoral Indonesia (FSP Paras Indonesia).

Awal mula terjadinya perselisihan antara Nana Kusnaedi dengan REDTOP Hotel \& Convention Center karena pada tanggal 1 September 2015 REDTOP 
Hotel \& Convention Center menerbitkan Surat Keputusan No. : 276/HR/IX/15, tentang Perpindahan Karyawan (MUTASI), yang pada pokoknya surat tersebut menerangkan bahwa REDTOP Hotel \& Convention Center melakukan mutase terhadap Nana Kusnaedi dari jabatan lama yaitu Attendant pada F \& B Dept. dimutasikan ketempat yang baru yakni Gardener (Pertamanan) / Housekeeping Dept. terhitung sejak 9 September 2015.Atas mutasi tersebut, Nana Kusnaedi menyampaikan surat mengenai keluh kesahnya yang ditujukan kepada atasannya langsung F \& B Director, Excom, Dir. HRD dan General Manager sesuai ketentuan Pasal 50 Peraturan Perusahaan, yang pada pokoknya dalam surat dimaksud Nana Kusnaedi telah menyampaikan keluh kesah dan keberatannya untuk dimutasikan ke bagian Gardener (pertamanan) pada Housekeeping Dept, dengan alasan mutasi tersebut pelaksanaannya tidak sesuai dengan ketentuan Pasal 11 point 1 Peraturan Perusahaan, dimana ketentuan dalam Peraturan Perusahaan ditetapkan bahwa mutasi dilaksanakan harus sesuai dengan keterampilan dan keahlian yang dimiliki oleh Pekerja yang bersangkutan, sementara itu keterampilan dan keahlian yang dimiliki oleh Nana Kusnaedi adalah pada bidang F \& B Service (pelayan tamu) bukan dibidang Gardener (pertamanan).

REDTOP Hotel \& Convention Center menanggapinya dengan tetap pada pendiriannya semula untuk melakukan mutasi kepada Nana Kusnaedi hanya dengan alasan lebih mengutamakan kepentingan dan kebutuhan perusahaan tanpa mempertimbangkan dan mengedepankan hak-hak Nana Kusnaedi selaku Pekerja untuk ditempatkan pada bagian yang sesuaidengan keterampilan dan keahlian yang dimilikinya sebagaimana yang telah ditetapkan dalam peraturan perusahaan.

Selanjutnya REDTOP Hotel \& Convention Center melakukan pemutusan hubungan kerja terhadap PENGGUGAT, dimana dalam surat dimaksud tidak memiliki nomor maupun perihal surat dan pencantuman tahunnya pun keliru yakni 4 Desember 2016. Selain itu apa yang tersebut dalam surat dimaksud mengenai pemberian uang masa kerja, uang pisah, penggantian uang pengobatan dan perumahan $15 \%$ dan penggantian cuti yang belum diambil hanya bohong belaka, karena pada faktanya sampai dengan sekarang hak-hak Nana Kusnaedi 
atas kompensasi pemutusan hubungan kerja belum juga dibayarkan meskipun telah dikeluarkannya anjuran tertulis oleh mediator Pengadilan Hubungan Industrial.

Tindakan REDTOP Hotel \& Convention Center yang melakukan pemutusan hubungan kerja secara sewenang-wenang terhadap Nana Kusnaedi tidak dapat dibernarkan oleh hukum, karena terbukti pemutusan hubungan kerja dimaksud belum memperoleh penetapan dari lembaga penyelesaian perselisihan hubungan industrial, sehingga tindakan REDTOP Hotel \& Convention Center yang demikian jelas sangat bertentangan dengan ketentuan Pasal 151 Ayat 3 UndangUndang Nomor 13 Tahun 2003 Tentang Ketenagakerjaan berbunyi dalam hal perundingan sebagaimana dimaksud dalam ayat 2 benar-benar tidak menghasilkan persetujuan, pengusaha hanya dapat memutuskan hubungan kerja dengan pekerja atau buruh setelah memperoleh penetapan dari lembaga penyelesaian perselisihan hubungan industrial.

Pemutusan hubungan kerja yang dilakukan oleh REDTOP Hotel \& Convention Center terhadap Nana Kusnaedi belum memperoleh penetapan dari lembaga penyelesaian perselisihan hubungan industrial, dalam hal ini Pengadilan Hubungan Industrial pada Pengadilan Negeri Jakarta Pusat, maka sesuai ketentuan yang dimaksud dalam Pasal 155 Ayat 1 Undang-Undang Nomor 13 Tahun 2013 Tentang Ketenagakerjaan pemutusan hubungan kerja yang dilakukan oleh REDTOP Hotel \& Convention Center terhadap Nana kusnaedi adalah batal demi hukum, yang artinya secara hukum hubungan kerja antara Nana Kusnaedi dan REDTOP Hotel \& Convention Center belum terputus.

Perselisihan antara Nana Kusanedi dan REDTOP Hotel \& Convention Center telah menempuh upaya untuk menyelesaikannya, baik secara bipartite maupun melalui mediasi pada Kantor Suku Dinas Tenaga Kerja dan Transmigrasi Kota Administrasi Jakarta Pusat, namun tidak tercapai kesepakatan, oleh karenanya Mediator Hubungan Industrial megeluarkan anjuran tertulis No. : 989/-1.835.1. tertanggal 3 Mei 2016.

Mediator menganjurkan dalam diktum anjurannya menganjurkan agar REDTOP Hotel \& Convention Center memberikan uang pesangon sebesar 1 
(satu) kali ketentuan Pasal 156 Ayat (2), uang penghargaan masa kerja sesuai ketentuan Pasal 156 Ayat (3) dan penggantian hak sesuai ketentuan Pasal 156 Ayat (4) Undang-Undang Nomor 13 Tahun 2003 Tentang Ketenagakerjaan kepada Penggugat dan memberikan upah Penggugat yang belum dibayarkan oleh Tergugat.

Penggugat menyatakan kesetujuannya atas anjuran mediator, dimana anjuran tersebut dinilai sesuai dengan ketentuan Pasal 161 Ayat (3) Undang-Undang Nomor 13 Tahun 2003, namun Tergugat menyatakan menolak anjuran tertulis tersebut dengan alasan yang pada intinya keberatan terhadap pertimbangan dan anjuran mediator yang memberikan pesangon kepada Penggugat padahal jelasjelas terdapat bukti dan saksi yang memperkuat bahwa Penggugat telah melakukan pelanggaran Pasal 45 Ayat (2) jo Pasal 46 ayat (17) peraturan Perusahaan REDTOP Hotel \& Convention Center serta keberatan atas anjuran mediator mengenai pemberian upah kepada Penggugat yang belum dibayarkan oleh pihak perusahaan, sehingga perselisihan tersebut belum terselesaikan karena belum tercapai kesepakatan.

Pemutusan hubungan kerja yang dilakukan oleh Penggugat terhadap Tergugat batal demi hukum dikarenakan belum memperoleh penetapan dari lembaga penyelesaian Pengadilan Hubungan Industrial, maka hubungan kerja antara Penggugat dengan Tergugat harus dinyatakan belum terputus, oleh sebab itu Tergugat harus dihukum untuk tetap membayarkan hak-hak Penggugat atas upah yang belum dibayarkan oleh Tergugat sejak bulan Desember 2015 sampai adanya putusan yang berkekuatan hukum tetap (Inkracht Van Gewisjde) sesuai ketentuan Pasal 93 Ayat (2) huruf f, jo Pasal 155 Ayat (3) Undang-Undang Nomoe 13 Tahun 2003 tentang Ketenagakerjaan jo Putusan Mahkamah Konstitusi No: 37/PUU-IX/2011.

Selain hal diatas, sesuai ketentuan Permenaker No: PER-04/MEN/1994 tentang Tunjangan Hari Raya (yang selanjutnya disebut THR) Keagamaan bagi pekerja di perusahaan yang telah dirubah dengan Permenaker No: 6 Tahun 2016 dan karena terbukti Tergugat belum melaksanakan kewajibannya dalam membayarkan THR Keagamaan kepada Penggugat, dimana Hari Raya Idul Fitri 
1437H yang jatuh bertepatan dengan tanggal 6-7 Juli 2016, maka Tergugat harus dihukum untuk membayarkan THR Keagamaan di tahun 2016 kepada Penggugat sebanyak 1 (satu) bulan upah yakni sebesar Rp. 3.323.000 (tiga juta tiga ratus dua puluh tiga ribu rupiah)

Berdasarkan ketentuan peraturan perundang-undangan sebagaimana dimaksud, maka sangat berdasar hukum jika Penggugat menuntut dan mengajukan permohonan kepada yang terhormat majelis hakim yang mememeriksa dan memutus perkara a quo untuk diputuskan hubungan kerjanya dengan Tergugat, dan atas pemutusan hubungan kerja dimaksud sangat patut dan adil jika Tergugat dihukum untuk membayarkan secara tunai berupa kompensasi pemutusan hubungan kerja beserta seluruh hak-hak yang seharusnya diterima Penggugat.

Berdasarkan alasan-alasan, fakta dan alas hukum sebagaimana yang terurai diatas, dalam putusannya majelis hakim menghukum tergugat dengan amar putusan sebagai berikut: ${ }^{6}$

\section{E N G A D I L I:}

\section{DALAM EKSEPSI:}

1. Menolak eksepsi Tergugat untuk seluruhnya;

\section{DALAM POKOK PERKARA:}

1. Mengabulkan gugatan Penggugat untuk sebagian;

2. Menyatakan putus hubungan kerja antara Penggugat dengan Tergugat sejak tanggal 4 Desember 2015;

3. Menghukum Tergugat untuk membayar secara tunai kepada Penggugat uang pisah yang seleuruhnya berjumlah sebesar Rp. 6.646 .000 (enam juta enam ratus empat puluh enam ribu rupiah);

4. Memerintahkan Tergugat untuk membuat dan memberikan surat pengalaman bekerja kepada Penggugat secara baik dan benar;

5. Menolak Petitum Tergugat selain dan selebihnya;

\footnotetext{
${ }^{6}$ Putusan Pengadilan Hubungan Industrial Jakarta Pusat Nomor 210/Pdt.SusPHI/2016/PN.JKT.PST.
} 
6. Membebankan biaya perkara kepada Negara sebesar Rp. 356.000,00 (tiga ratus lima puluh enam ribu rupiah).

Pengaturan mengenai penempatan tenaga kerja pada dasarnya sudah diatur dalam Pasal 32 Ayat (2) Undang-Undang Nomor 13 Tahun 2003 tentang Ketenagakerjaan yang menyatakan bahwa penempatan tenaga kerja diarahkan untuk menempatkan tenaga kerja pada jabatan yang tepat sesuai dengan keahlian, ketrampilan, bakat, minat, dan kemampuan dengan memperhatikan harkat, martabat, hak asasi, dan perlindungan hukum.

Pengusaha diwajibkan membayar uang pesangon dan atau uang penghargaan masa kerja dan uang penggantian hak dalam hal terjadi pemutusan hubungan kerja sesuai dengan ketentuan Pasal 156 Ayat (1) Undang-Undang Ketenagakerjaan

Selanjutnya dalam Ayat (2) diatur lebih lanjut perhitungan uang pesangon sebagaimana dimaksud dalam Ayat (1) paling sedikit sebagai berikut:

a. Masa kerja kurang dari 1 (satu) tahun, 1 (satu) bulan upah;

b. Masa kerja 1 (satu) tahun atau lebih tetapi kurang dari 2 (dua) tahun, 2 (dua) bulan upah;

c. Masa kerja 2 (dua) tahun atau lebih tetapi kurang dari 3 (tiga) tahun, 3 (tiga) bulan upah;

d. Masa kerja 3 (tiga) tahun atau lebih tetapi kurang dari 4 (empat) tahun, 4 (empat) bulan upah;

e. Masa kerja 4 (empat) tahun atau lebih tetapi kurang dari 5 (lima) tahun, 5 (lima) bulan upah;

f. Masa kerja 5 (lima) tahun atau lebih, tetapi kurang dari 6 (enam) tahun, 6 (enam) bulan upah;

g. Masa kerja 6 (enam) tahun atau lebih tetapi kurang dari 7 (tujuh) tahun, 7 (tujuh) bulan upah;

h. Masa kerja 7 (tujuh) tahun atau lebih tetapi kurang dari 8 (delapan) tahun, 8 (delapan) bulan upah;

i. Masa kerja 8 (delapan) tahun atau lebih, 9 (sembilan) bulan upah. 
Perhitungan uang penghargaan masa kerja sebagaimana dimaksud dalam ayat

(1) ditetapkan sebagai berikut:

a. Masa kerja 3 (tiga) tahun atau lebih tetapi kurang dari 6 (enam) tahun, 2 (dua) bulan upah;

b. Masa kerja 6 (enam) tahun atau lebih tetapi kurang dari 9 (sembilan) tahun, 3 (tiga) bulan upah;

c. Masa kerja 9 (sembilan) tahun atau lebih tetapi kurang dari 12 (dua belas) tahun, 4 (empat) bulan upah;

d. Masa kerja 12 (dua belas) tahun atau lebih tetapi kurang dari 15 (lima belas) tahun, 5 (lima) bulan upah;

e. Masa kerja 15 (lima belas) tahun atau lebih tetapi kurang dari 18 (delapan belas) tahun, 6 (enam) bulan upah;

f. Masa kerja 18 (delapan belas) tahun atau lebih tetapi kurang dari 21 (dua puluh satu) tahun, 7 (tujuh) bulan upah;

g. Masa kerja 21 (dua puluh satu) tahun atau lebih tetapi kurang dari 24 (dua puluh empat) tahun, 8 (delapan) bulan upah;

h. Masa kerja 24 (dua puluh empat) tahun atau lebih, 10 (sepuluh ) bulan upah. Uang penggantian hak yang seharusnya diterima sebagaimana dimaksud dalam ayat (1) meliputi:

a. Cuti tahunan yang belum diambil dan belum gugur;

b. Biaya atau ongkos pulang untuk pekerja/buruh dan keluarganya ke tempat di mana pekerja/buruh diterima bekerja;

c. Penggantian perumahan serta pengobatan dan perawatan ditetapkan $15 \%$ (lima belas perseratus) dari uang pesangon dan/atau uang penghargaan masa kerja bagi yang memenuhi syarat;

d. Hal-hal lain yang ditetapkan dalam perjanjian kerja, peraturan perusahaan atau perjanjian kerja bersama.

Menurut Fitzgerald sebagaimana dikutip Satjipto Raharjo awal mula dari munculnya teori perlindungan hukum ini bersumber dari teori hukum alam atau aliran hukum alam. Aliran ini dipelopori oleh Plato,Aristoteles (murid Plato), dan Zeno (pendiri aliran Stoic). Menurut aliran hukum alam menyebutkan bahwa 
hukum itu bersumber dari Tuhan yang bersifat universal dan abadi, serta antara hukum dan moral tidak boleh dipisahkan. Para penganut aliran ini memandangbahwa hukum dan moral adalah cerminan dan aturan secara internal dan eksternaldari kehidupan manusia yang diwujudkan melalui hukum dan moral. $^{7}$

Fitzgerald menjelaskan teori pelindungan hukum Salmond bahwa hukum bertujuan mengintegrasikan dan mengkoordinasikan berbagai kepentingan dalam masyarakat karena dalam suatu lalu lintas kepentingan, perlindungan terhadap kepentingan tertentu hanya dapat dilakukan dengan cara membatasi berbagai kepentingan di lain pihak. Kepentingan hukum adalah mengurusi hak dan kepentingan manusia, sehingga hukum memiliki otoritas tertinggi untuk menentukan kepentingan manusia yang perlu diatur dan dilindungi. Perlindungan hukum harus melihat tahapan yakni perlindungan hukum lahir dari suatu ketentuan hukum dan segala peraturan hukum yang diberikan oleh masyarakat yang pada dasarnya merupakan kesepakatan masyarakat tersebut untuk mengatur hubungan perilaku antara anggota-anggota masyarakat dan antara perseorangan dengan pemerintah yang dianggap mewakili kepentingan masyarakat. ${ }^{8}$

Menurut Satjipto Raharjo, perlindungan hukum adalah memberikan pengayoman terhadap hak asasi manusia (HAM) yang dirugikan orang lain dan perlindungan itu di berikan kepada masyarakat agar dapat menikmati semua hakhak yang diberikan oleh hukum. Hukum dapat difungsikan untuk mewujudkan perlindungan yang sifatnya tidak sekedar adaptif dan fleksibel, melainkan juga prediktif dan antisipatif. Hukum dibutuhkan untuk mereka yang lemah dan belum kuat secara sosial, ekonomi dan politik untuk memperoleh keadilan sosial. ${ }^{9}$

Phillipus M. Hadjon menyatakan bahwa perlindungan hukum bagi rakyat sebagai tindakan pemerintah yang bersifat preventif dan represif. Perlindungan hukum yang preventif bertujuan untuk mencegah terjadinya sengketa, yang mengarahkan tindakan pemerintah bersikap hati-hati dalam pengambilan

\footnotetext{
hal.53.

${ }^{7}$ Satjipto Rahardjo, Ilmu Hukum, Cetakan ke-1, (Bandung: PT. Citra Aditya Bakti, 2000),

${ }^{8}$ Ibid., hal.54

${ }^{9}$ Ibid., hal.55
} 
keputusan berdasarkan diskresi, dan perlindungan yang represif bertujuan untuk menyelesaikan tejadinya sengketa, termasuk penangananya di lembaga peradilan. $^{10}$

Sesuai dengan uraian di atas dapat dinyatakan bahwa fungsi hukum adalah melindungi rakyat dari bahaya dan tindakan yang dapat merugikan danmenderitakan hidupnya dari orang lain, masyarakat maupun penguasa. Selain itu berfungsi pula untuk memberikan keadilan serta menjadi sarana untuk mewujudkan kesejahteraan bagi seluruh rakyat.

Perlindungan hukum bila dijelaskan harfiah dapat menimbulkan banyak persepsi. Sebelum mengurai perlindungan hukum dalam makna yang sebenarnya dalam ilmu hukum, menarik pula untuk mengurai sedikit mengenai pengertianpengertian yang dapat timbul dari penggunaan istilah perlindungan hukum, yakni perlindungan hukum bisa berarti perlindungan yang diberikan terhadap hukum agar tidak ditafsirkan berbeda dan tidak cederai oleh aparat penegak hukum dan juga bisa berarti perlindungan yang diberikan oleh hukum terhadap sesuatu.

Kata mutasi atau pemindahan oleh sebagian masyarakat sudah dikenal, baik dalam lingkungan maupun di luar lingkungan perusahaan (pemerintahan). Mutasi adalah kegiatan memindahkan tenaga kerja dari satu tempat tenaga kerja ke tempat kerja lain. Akan tetapi mutasi tidak selamanya sama dengan pemindahan. Mutasi meliputi kegiatan memindahkan tenaga kerja, pengoperan tanggung jawab, pemindahan status ketenagakerjaan, dan sejenisnya. Adapun pemindahan hanya terbatas pada mengalihkan tenaga kerja dari satu tempat ke tempat lain. ${ }^{11}$

Mutasi atau transfer adalah perpindahan pekerjaan seseorang dalam suatu organisasi yang memiliki tingkat level yang sama dari posisi perkerjaan sebelum mengalami pindah kerja. Kompensasi gaji, tugas dan tanggung jawab yang baru umumnya adalah sama seperti sedia kala. Mutasi atau rotasi kerja dilakukan untuk menghindari kejenuhan pegawai atau pegawai pada rutinitas pekerjaan yang terkadang membosankan serta memiliki fungsi tujuan lain supaya seseorang dapat

\footnotetext{
${ }^{10}$ Phillipus M. Hadjon, Perlindungan Hukum Bagi Rakyat Indonesia, Cetakan ke-1, (Surabaya: PT. Bina Ilmu,1987), hal.29.

11 Malayu, Manajemen Sumber Daya Manusia, Cetakan ke-1, (Jakarta: Bumi Aksara, 2008), hal.24.
} 
menguasai dan mendalami pekerjaan lain di bidang yang berbeda pada suatu perusahaan. Transfer terkadang dapat dijadikan sebagai tahapan awal atau batu loncatan untuk mendapatkan promosi di waktu mendatang. Hakekatnya mutasi adalah bentuk perhatian pimpinan terhadap bawahan.

Kegiatan memindahkan pegawai dari suatu bagian (tempat kerja) ke bagian yang lain bukanlah merupakan kegiatan yang dianggap tabuh. Bahkan kegiatan ini dilakukan untuk mengembangkan pegawai. Hal ini disebabkan karena mutasi diperlukan agar pegawai memperoleh pengetahuan dan pengalaman baru yang lebih luas.

Tujuan mutasi adalah sebagai berikut:

1. Untuk meningkatkan poduktivitas karyawan;

2. Untuk menciptakan keseimbangan anatar tenaga kerja dengan komposisi pekejaan atau jabatan;

3. Untuk memperluas atau menambah pengetahuan pegawai;

4. Untuk menghilangkan rasa bosan/jenuh tehadap pekerjaannya;

5. Untuk memberikan perangsang agar pegawai mau berupaya meningkatkan karir yang lebih tinggi;

6. Untuk alat pendorong agar spirit kerja meningkat melalui pesaingan terbuka.

Sebab-sebab pelaksanaan mutasi digolongkan sebagai berikut:

1. Permintaan sendiri

Mutasi atas permintaan sendiri adalah mutasi yang dilakukan atas keinginan sendiri dari karywan yang bersangkutan dan dengan mendapat persetujuan pimpinan organisasi. Mutasi pemintaan sendiri pada umumnya hanya pemindahan jabatan yang peringkatnya sama baik, antarbagian maupun pindah ke tempat lain.

\section{Alih Tugas Produktif (ATP)}

Alih tugas produktif adalah mutasi karena kehendak pimpinan perusahaan untuk meningkatkan produksi dengan menempatkan karywan yang bersangkutan ke jabatan atau pekerjannya yang sesuai dengan kecakapannya.

Mutasi yang dilaksanakan dapat meningkatkan efektivitas dan efisiensi oleh karena itu perlu ada evaluasi pada setiap perkerja secara berkesinambungan secara 
objekif. Dalam melaksanakan mutasi harus dipertimbangkan faktor-faktor yang dianggap objektif dan rasional, yaitu: ${ }^{12}$

a. Mutasi disebabkan kebijakan dan peraturan pemerintah;

b. Mutasi atas dasar prinsip The right man on the right place;

c. Mutasi sebagai dasar untuk meningkatkan profesionalitas kerja;

d. Mutasi sebagai media kompetisi yang maksimal;

e. Mutasi sebagai langkah untuk promosi;

f. Mutasi untuk mengurangi labour turn over;

g. Mutasi harus terkoordinasi.

Ada 3 dasar pelaksanaan mutasi menurut Malayu, yaitu:

a. Merit System (career system)

Merit system adalah mutasi karyawan yang didasarkan atas landasan yang bersifat ilmiah, obyektif dan prestasi kerja. Sistem ini merupakan sistem yang baik, karena:

1) Output dan produktivitas kerja meningkat

2) Semangat kerja meningkat

3) Jumlah kesalahan yang dibuat menurun

4) Absensi dan disiplin karyawan semakin baik

5) Jumlah kecelakaan akan menurun

b. Seniority System

Seniority System adalah mutasi yang didasarkan atas landasan masa kerja, usia, pengalaman kerja dari karyawan yang bersangkutan. Sistem ini tidak obyektif, karena orang dimutasikan kecakapannya dalam memangku jabatan baru itu belum terjamin.

c. Spoil system

Spoil System adalah mutasi yang didasarkan atas landasan kekeluargaan. Sistem ini kurang baik karena didasarkan atas pertimbangan suka/tidak suka (like or dislike).

${ }^{12}$ Sudarwan Danim, Motivasi Kepemimpinan dan Efektivitas Kelompok, Cetakan ke-1, (Jakarta: Rineka Cipta, 2009), hal.56. 
Berdasarkan Pasal 156 Ayat (2) Undang-Undang Nomor 13 Tahun 2003 tentang Ketenagakerjaan maka uang pesangon yang seharusnya atau sekurangkurangnya diterima oleh pekerja adalah sebagai berikut:

Uang Pesangon :

1 X 9 X Rp. 3.323.000.00 $=$ Rp. 29.907.000.00

Uang Penghargaan Masa Kerja :

6 X Rp. 3.323.000.00

Uang Penggantian Hak :

15\% X Rp. 49.845.000.00

$=$ Rp. 7.467.750.00

Upah Proses Desember $2015 \mathrm{~s} / \mathrm{d}$ Oktober $2016=$ Rp. 36.553 .000 .00

@ Rp. 3.323.000.00 X 11

THR Keagamaaan Tahun 2015

$=\underline{\text { Rp. } 3.323 .000}$

Total $=$ Rp. 97.197 .750

Terbilang : (Sembilan puluh tujuh juta seratus sembilan puluh tujuh ribu tujuh ratus lima puluh rupiah).

Penulis melakukan wawanara dengan Bapak Juanda Pangaribuan, beliau berpendapat pekerja masih berhak mendapat pesangon bila terjadi pemutusan hubungan kerja karena mutasi bukanlah merupakan pelanggaran hukum yang menimbulkan akibat dan kerugian. ${ }^{13}$ Mutasi merupakan sebuah pelanggaran syarat kerja atau dikenal sebagai pelanggaran indsipliner. Selain itu mutasi juga bisa dianggap sebagai perlawanan atas perintah atasan namun melawan perintah atasan bukan merupakan pelanggaran hukum. Kalaupun melanggar pekerja juga tetap harus mendapat pesangon. Pada prakteknya banyak pengusaha menghindari pembayaran uang pesangon. Karena dengan meneribitkan SP maka pengusaha harus memberikan pesangon. Oleh karena itu banyak pengusaha yang langsung mengeluarkan surat pemutusan hubungan kerja dengan harapan akan muncul perdebatan hukum di pengadilan. Aparat penegak hukum kerap lupa membedah apakah menolak mutasi merupakan sebuah pelanggaran hukum atau tidak.

${ }^{13}$ Penulis, Wawancara, dengan Juanda Pangaribuan, selaku Mantan Hakim Ad Hoc Pengadilan Hubungan Industrial, (Jakarta: Dana Graha, 30 Mei 2018). 
Penulis berpendapat adanya kesesuaian serta ketidaksesuaian antara undangundang, Perjanjian Kerja Bersama serta teori. Ketidaksesuaian ini tercermin dari tidak diperolehnya uang pesangon, serta upah proses yang sudah sepatutnya dipeoleh pekerja. Uang pesangon merupakan hak pekerja yang sudah diatur secara jelas dalam undang-undang. Terlepas dari pelanggaran atau kelalaian yang dilakukan oleh pekerja, pekerja tetap berhak atas uang pesangon ketika terjadi pemutusan hubungan kerja. Besarnya uang pesangon yang diterima bergantung pada alasan pemutusan hubungan kerja, dalam kasus ini berdasarkan hasil wawancara dengan Bapak Juanda Pangaribuan pekerja dinilai layak untuk menerima uang pesangon sebesar 1 (satu) kali upah. Kesesuaian antara teori dengan kasus ini tercermin dari terlaksananya perlindungan hukum preventif dan represif.

\section{A. Akibat Hukum Terhadap Pekerja Yang Diputus Hubungan Kerjanya} Karena Pekerja Menolak Mutasi Pada PT Sanggraha Dhika (Studi Kasus Putusan Nomor 210/Pdt.Sus-PHI/2016/PN.JKT.PST)

Pengaturan tentang uang pesangon diatur dalam Pasal 163 Undang-Undang Nomor 13 Tahun 2003 tentang Ketenagakerjaan. Pengusaha dapat melakukan pemutusan hubungan kerja terhadap pekerja atau buruh dalam hal terjadi perubahan status, penggabungan, peleburan, atau perubahan kepemilikan perusahaan dan pekerja atau buruh tidak bersedia melanjutkan hubungan kerja, maka pekerja atau buruh berhak atas uang pesangon sebesar 1 (satu) kali sesuai ketentuan Pasal 156 Ayat (2), uang perhargaan masa kerja 1 (satu) kali ketentuan Pasal 156 Ayat (3) dan uang penggantian hak sesuai ketentuan dalam Pasal 156 Ayat (4). Pengusaha dapat melakukan pemutusan hubungan kerja terhadap pekerja/buruh karena perubahan status, penggabungan, atau peleburan perusahaan, dan pengusaha tidak bersedia menerima pekerja atau buruh di perusahaannya, maka pekerja atau buruh berhak atas uang pesangon sebesar 2 (dua) kali ketentuan Pasal 156 Ayat (2), uang penghargaan masa kerja 1 (satu) kali ketentuan dalam Pasal 156 Ayat (3), dan uang penggantian hak sesuai ketentuan dalam Pasal 156 ayat (4). Besaran pesangon yang diterima oleh pekerja ketika terjadi pemutusan hubungan kerja sudah diatur secara normatif pada Pasal 
163 sampai dengan Pasal 172 Undang-Undang Nomor 13 Tahun 2003 tentang Ketenagakerjaan.

Pada dasarnya mutasi secara garis besar dapat dibagi menjadi dua yakni mutasi yang dilakukan dengan alasan yang objektif dan mutasi yang dilakukan dengan alasan subjektif. Mutasi dikatakan objektif adalah ketika mutasi tersebut dilakukan berdasarkan undang-undang, PP, Perjanjian Kerja Bersama yang berlaku. Mutasi objektif adalah mutasi yang dilakukan murni untuk kepentingan perusahaan. Mutasi subjektif dilakukan dengan alasan karena adanya sebuah sentiment serta faktor-faktor lainnya. Pada umumnya mutasi ini dilakukan karena alasan pribadi serta tidak berdasarkan undang-undang, PP, Perjanjian Kerja Bersama yang berlaku.

Pada kasus Nana, mutasi yang dilakukan oleh perusahaan dapat dikatakan sebagai mutasi yang bersifat subjektif. Pertama, perusahaan melakukan mutasi terhadap Nana tidak sesuai dengan ketentuan Pasal 32 Ayat (2) Undang-Undang Nomor 13 Tahun 2003 tentang Ketenagakerjaan serta Perjanjian Kerja Bersama yang sudah disepakati bersama dimana Nana dimutasi ke bidang yang tidak sesuai dengan keterampilan yang ia miliki. Kedua, perusahaan melakukan mutasi kemudian pemutusan hubungan kerja tanpa pemberitahuan terlebih dahulu kepada Nana.

Menurut Bapak Juanda Pangaribuan, mutasi subjektif tidak didasarkan pada undang-undang, Perjanjian Kerja dan Perjanjian Kerja Bersama serta bertentangan dengan undang-undang maka pekerja berhak atas 2 (dua) kali uang pesangon karena alasan pemutusan hubungan kerja bukan merupakan kesalahan pekerja. Sebaliknya bila pekerja menolak mutasi yang didasarkan alasan yang objektif maka hanya mendapat 1 (satu) kali uang pesangon. Sehingga tidak dapat digeneralisir hak seorang pekerja ketika di pemutusan hubungan kerja. Karena variabel pesangonnya berbeda, bergantung dari alasan mutasi.

Akibat hukum dari pemutusan hubungan kerja yang dilakukan oleh perusahaan terhadap pekerja bergantung pada hal yang melatarbelakangi pemutusan hubungan kerja itu sendiri, dalam hal ini adalah mutasi. Mutasi subjektif dan objektif memiliki akibat hukum yang berbeda. Sehingga akibat 
hukum yang timbul dari pemutusan hubungan kerja yang terjadi antara Nana dengan PT Sanggraha Dhika seharusnya adalah dengan dibayarkannya uang pesangon Nana sebesar 1 (satu) kali upah sesuai dengan Pasal 156 Ayat (2) Undang-Undang Nomor 13 Tahun 2003 tentang Ketenagakerjaan.

Berdasarkan uraian diatas maka ada ketidaksesuaian antara akibat hukum dengan peristiwa hukum yang terjadi. Ketidaksesuaian ini terletak pada tidak diterimanya uang pesangon sebesar 1 (satu) kali upah yang seharusnya diterima oleh Nana seperti yang sudah diatur pada Pasal 156 Ayat (2) Undang-Undang Nomor 13 Tahun 2003 tentang Ketenagakerjaan. Perlindungan hukum represif yang sudah terlaksana dinilai tidak mampu melindungi hak pekerja.

\section{PENUTUP}

\section{A. Kesimpulan}

1. Perlindungan hukum yang sepatutnya diterima oleh pekerja yang diputus hubungan kerjanya karena menolak mutasi adalah dalam bentuk pemberian pesangon sesuai dengan ketentuan Pasal 156 Ayat (2) Undang-Undang Nomor 13 Tahun 2003 tentang Ketenagakerjaan. Pada kasus ini terdapat ketidaksesuaian dan kesesuaian antara undang-undang, Perjanjian Kerja Bersama serta teori. Ketidaksesuaian ini tercermin dari tidak diperolehnya uang pesangon, serta upah proses yang sudah sepatutnya dipeoleh pekerja. Uang pesangon merupakan hak pekerja yang sudah diatur secara jelas dalam undang-undang. Kesesuaian antara teori dengan kasus ini tercermin dari terlaksananya perlindungan hukum preventif dan represif. Terlepas dari pelanggaran atau kelalaian yang dilakukan oleh pekerja, pekerja tetap berhak atas uang pesangon ketika terjadinya pemutusan hubungan kerja. Besarnya uang pesangon yang diterima bergantung pada alasan pemutusan hubungan kerja, dalam kasus ini berdasarkan hasil wawancara dengan Bapak Juanda Pangaribuan pekerja dinilai layak untuk menerima uang pesangon sebesar 1 (satu) kali upah, 6 (enam) kali uang penghargaan masa kerja dan 15\% uang penggantian hak. Mengacu pada anjuran Mediator Pengadilan Hubungan Industrial Nomor 989/-1.835.1. tertanggal 3 Mei 2016 yang sudah disesuaikan 
dengan Pasal 156 Ayat (2) Undang-Undang Nomor 13 Tahun 2003 tentang Ketenagakerjaan. Uang pesangon yang sepatutnya diterima oleh pekerja atau sekurang-kurangnya adalah sebagai berikut:

Uang Pesangon :

1 X 9 X Rp. 3.323.000.00 $=$ Rp. 29.907.000.00

Uang Penghargaan Masa Kerja :

6 X Rp. 3.323.000.00

Uang Penggantian Hak :

$15 \%$ X Rp. 49.845.000.00 = Rp. 7.467.750.00

Upah Proses Desember 2015 s/d Oktober $2016=$ Rp. 36.553.000.00

$@$ Rp. 3.323.000.00 X 11

THR Keagamaaan Tahun 2015

$$
=\underline{\operatorname{Rp} .3 .323 .000}
$$

Total

$$
=\text { Rp. 97.197.750 }
$$

Terbilang : (Sembilan puluh tujuh juta seratus sembilan puluh tujuh ribu tujuh ratus lima puluh rupiah).

2. Akibat hukum terhadap pekerja yang diputus hubungan kerjanya karena menolak mutasi bergantung pada sifat mutasi itu sendiri, objektif atau subjektif. Mutasi yang bersifat subjektif tidak didasarkan pada undangundang, perjanjian kerja dan perjanjian kerja bersama serta bertentangan dengan undang-undang maka pekerja berhak atas 2 (dua) kali upah karena alasan pemutusan hubungan kerja bukan merupakan kesalahan pekerja. Sebaliknya bila pekerja menolak mutasi yang didasarkan alasan yang objektif maka hanya mendapat 1 (satu) kali uang pesangon. Sehingga tidak dapat digeneralisir hak seorang pekerja ketika diputus hubungan kerjanya karena variabel pesangonnya berbeda, bergantung dari alasan mutasi. Terdapat ketidaksesuaian antara akibat hukum dengan peristiwa hukum yang terjadi. Ketidaksesuaian ini terletak pada tidak diterimanya uang pesangon sebesar 1 (satu) kali upah yang seharusnya diterima oleh Nana seperti yang sudah diatur pada Pasal 156 Ayat (2) Undang-Undang Nomor 13 Tahun 2003 tentang Ketenagakerjaan. Perlindungan hukum represif yang sudah terlaksana dinilai tidak mampu melindungi hak pekerja. 


\section{DAFTAR PUSTAKA}

\section{A. Buku}

Asikin, Zainal. Dasar-Dasar Hukum Perburuhan. (Jakarta: Raja Grafindo Persada, 2004).

Danim, Sudarwan. Motivasi Kepemimpinan dan Efektivitas Kelompok. (Jakarta: Rineka Cipta, 2009).

Djumialdji, F.X. Perjanjian Kerja. (Jakarta: Bumi Aksara, 1997).

Gultom, Sri Subiandini. Aspek Hukum Hubungan Industrial. (Jakarta: Hecca Mitra Utama, 2005).

Husni, Lalu. Pengantar Hukum Ketenagakerjaan Indonesia. (Jakarta: Raja Grafindo Persada, 2013).

Kartasapoetra. Gunawi. Hukum Perburuhan di Indonesia Berdasarkan Pancasila. (Jakarta: Bina Aksara, 1986).

Mahmudi. Manajemen Kinerja Sektor Publik. (Yogyakarta: UPP AMP YKPN, 2005).

Malayu. Manajemen Sumber Daya Manusia. (Jakarta: Bumi Aksara, 2008).

Soedjono, Wiwoho. Hukum Perjanjian Kerja Laut. (Jakarta: Bina Aksara, 1987).

Soepomo, Imam. Hukum Perburuhan Bidang Hubungan Kerja. (Jakarta: Djambatan, 1994).

Sutedi, Adrian. Hukum Perburuhan. (Jakarta: Sinar Grafika, 2009).

Wijayanti, Asri. Hukum Ketenagakerjaan Pasca Reformasi. (Jakarta: Sinar Grafika, 2014).

\section{B. Peraturan Perundangan}

Indonesia. Undang-Undang Nomor 13 Tahun 2003 tentang Ketenagakerjaan. Undang-Undang Nomor 2 Tahun 2004 tentang Penyelesaian Perselisihan Hubungan Industrial.

\section{Putusan Pengadilan}

Indonesia. Putusan Pengadilan Hubungan Industrial Jakarta Pusat Nomor: 210/Pdt.Sus-PHI/2016/PN.JKT.PST, 7 November 2016.

\section{Wawancara}

Pangaribuan, Juanda. Wawancara dengan penulis, Mantan Hakim Ad Hoc Pengadilan Hubungan Industrial, Gedung Dana Graha Lantai 7, Jakarta 30 Mei 2018.

Heriyanto, Yasman. Wawancara dengan penulis, Mediator Pengadilan Hubungan Industrial, Kementrian Ketenagakerjaan Lantai 3, Jakarta 31 Mei 2018. 